\title{
New records of Naidid worms (Oligochaeta: Naididae) in Euphrates River
}

Haifa J. Jaweir*

\author{
Elham O.S. Al- Janabi**
}

\author{
Received 20, December, 2012 \\ Accepted 3, March, 2014
}

\begin{abstract}
:
Naidid worms were sorted from 27 samples of aquatic macrophyta including ceratophyllum demersum, Potamogeton crispus and, Hydrilla verticellat with associated filamentous algae were collected from Euphrates River at Al-Mussayab city, $60 \mathrm{Km}$ southwest Baghdad. The result of sorted worms revealed the presence of eight species of subfamily Naidinae, which are consider as new records for Iraq, including Stephensoniana trivandrana; Paranais frici, Ophidonais serpentine, Specaria josinae, Dero (Dero) evelinae, Dero (Aulophorus) indicus, Nais pseudobtusa and finally $N$. stolci. This investigation includes morphological descriptions for each species illustrated by identification criteria photos.
\end{abstract}

Key words: Naididae;Naidid worms;Oligochaeta;Euphrates

\section{Introduction:}

Species of Naididae worms commonly inhabit sediments of rivers, streams and lakes (1). Due to their great ability to swim, they may have eyes, and are capable of exploring benthic habitat, (2) such as aquatic macrophytes (3), mosses and liverworts; (4), filamentous algae (5), sponges (6), and gastropod mollusks (7\&8). Sharapova (9) indicated that abundance of niadid worms correlated to the abundance of macrophyta, which their communities were affected by rouphness and lightness of the substrate.

Niadid worms previously, were grouped in the family Naididae ( 10 \&11), then according to data based on $18 \mathrm{~S}$ rDNA sequences and other molecular and morphological data $(2 \&$ 12) family Naididae and family Tubificidae were combined together in family Naididae, includes Naidid and Tubificiod naidid worms (13).

Niadid species are small and transparent worms, with few millimeters length, eye present in some species, dorsal chaetae begin from II or behind (III; IV, V or VI ), clitellum in few segments in the region of gonads (segments IV-V; V-VI or VII-VIII) ( 10). Reproduction mostly asexual by paratomy. They also can show incidentally sexual reproduction. The alternation of these two modes of reproduction can follow a regular annual cycle, but in some species sexual reproduction is rare and erratic (5). These group comprise two subfamilies, Subfamily Naidinae, and subfamily Pristininae (13).

Tubificoid naidid worms referred to the species of previous family Tubificidae, and all its five subfamilies (Tubificinae, Rhyacodrilinae, Phallodrilinae, Limnodriloidinae, and Telmatodrilinae) are now included within the family Naididae (13). This group of worms are the most common aquatic Oligochaeta in freshwater habitats. They are most commonly found in soft, organic matter rich sediments. Several species characteristically live at sites that receive organic pollution, as they are known to tolerate anoxic condition (

\footnotetext{
*Coll. Of Science for Women / University of Baghdad / Baghdad / Iraq
}

**Ministry of Education/Baghdad-Iraq. 
10). Some species are deposit feeders utilizing organic detritus and its associated microflora. These Oligochaetes are hermaphrodite and reproduce by cross-fertilization, while a few species of them may reproduce asexually by architomy (11).

Recently, there are some interest toward the identification of aquatic oligochaeta in Iraq , including Naidid species in different aquatic habitat ( $14,15,16,17,18,19,20 \quad \& 21)$. This study is concern with recording of some species collected from River Eughrates at Al-Mussayab city, 60Km, South Baghdad.

\section{Material and Methods:}

27 samples of aquatic macrophyta including Ceratpphyllum demersum, Potamogeton crispus and, Hydrilla verticellat with associated filamentous algae were collected from Euphrates River at Al-Mussayab city, $60 \mathrm{Km}$. southwest Baghdad, using a hand eradication tools. The collected plants were transferred to the laboratory where they placed in an aquarium of (20X 40X20) $\mathrm{cm}$. filled with river water, and aerated by electrical aquarium air pump. The sample was left for about 7-10 days at room temperature of $\left(20-25^{0} \mathrm{C}\right)$, before worms were collected carefully by dropping small amount of sediment using small dropper, add it to a $10 \mathrm{~cm}$ diameter petri dish and examined under dissecting microscope. Wet funnel procedure ( 21) also used to separate small worms from plants. The sorted worms then killed by adding few drops of $10 \%$ formalin, left for one hour before transferred to $70 \%$ ethanol as preservative.

The preserved specimens were mounted with polyvinyl lactophenol, and examined by compound microscope using $40 \mathrm{X}$ and 100X objective lenses. The identification criteria for each identified species were photographed by digital camera mounted to the Olympus compound microscope. Photoshop, Picasa and windows photo programs were used to arrange, clarified and magnified the photos. The specimens were identified according to ( $10 \& 11)$.

\section{Results and Disscussion:}

Eight species of subfamily Naidinae were observed as a new records for Iraq including.

1-Stephensoniana trivandrana (Aiyer,1926)

Number of individuals collected $=$ 56 with average length of $4.6 \mathrm{~mm}$. About $90 \%$ of individuals were collected during September and October .

In this species the body wall is brownish colour, encrusted with foreign matter and have thick glandular epithelium (Plate 1a) ; prostomium wide and rounded in shaped (plate1b) . Dorsal bundles beginning in II, with 24 hair and 2-3 needle anteriorly, reduced to 1-2 posteriorly. Needle chaetae simple pointed with tapering distal end ( Plate 1b). Ventral chaetae 4 per bundle anteriorly decreasing to 2 posteriorly, with upper tooth longer than lower one, the difference between the teeth increase toward backwards, all with proximal nodulus ( plate $1 \mathrm{c} \&$ d). No sexual individuals were detected during study period. This species is cosmopolitan and recorded in different places wideworld including India (22) ; USA ( 23) ; Africa ( 24); Argentina (25\&26); Biwa lake , central japan (27), the east coastal region of the Pasfic Ocean ( 11) ; Taiwan ( 28) ; and in Italy (29).

\section{2-Paranais frici Hrabe, 1941}

Eight specimens were sorted during Dec. - Feb. , with average length of $2.7 \mathrm{~mm}$ ( plate 2a). Genus Paranias is characterized by the absence of hair chaetae. The dorsa and the ventral bundles with the same type of chaetae, 
and dorsal bundle start from V. In $P$. frici, all chaetae have a longer upper tooth.( plate $2 b \& c$ ). This species is considered as a new record to Iraq, while the closely related species $P$. littoralis was recorded in Iraqi southern marshes by (15) and in Tigris river by (21). In Turkey $P$. frici was recorded by ( $29 \& 30)$. This species is very commom in freshwater habitat (11). It was also recorded in China by(31) ; in South Africa ( 33) ; and in Australia (34).

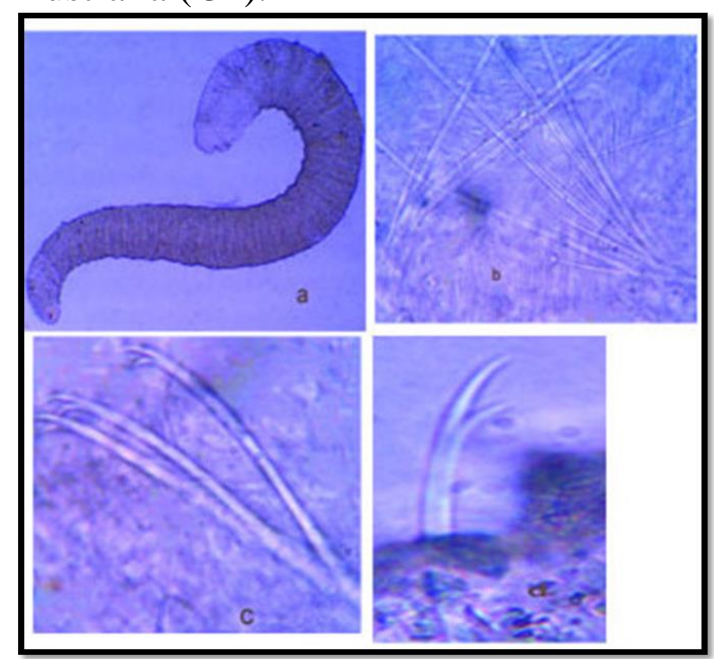

Plate 1: Stephensoniana trivandrana a-Whole worm; b- dorsal bundles canterior ventral bundle; $d$ - posterior ventral bundle

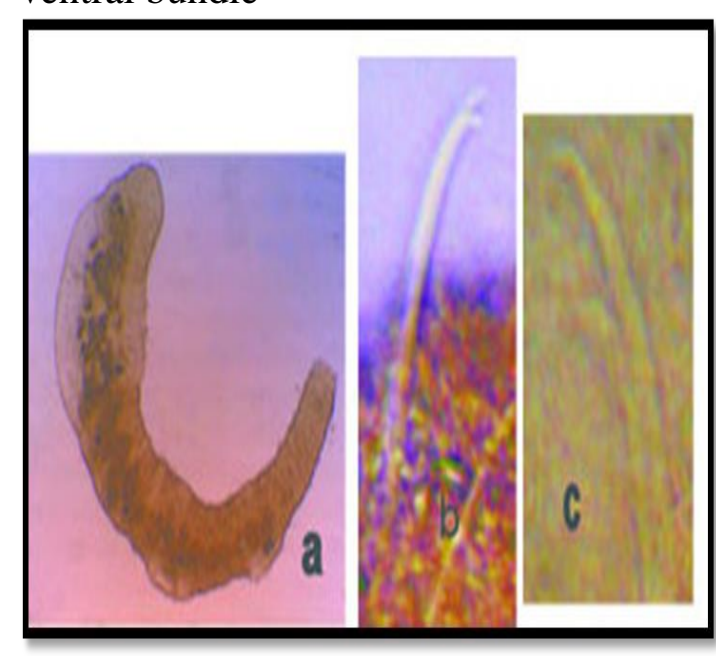

Plate 2: Paranais frici

a: Whole worm; b: dorsal chaetae ; c: ventral chaeta
3-Ophidonais serpentina (Müller, 1773)

Total number of 187 individuals were sorted during January - may samples, with a higher relative abundance in March and April. Average length was $4.8 \mathrm{~mm}$, body wall with sensory papillae, encrusting with foreign particles (Plate 3 a), Rectangular eyes presents). Sexual individuals were found in the samples during April, with broad clitellum (plate $3 \mathrm{~b}$ ), and a pair of sexual bundles of 2-3 penial chaetae, with a broader distal end forming a hook (plate $3 \mathrm{c}$ ). This species is characterizes by their dorsal chaetae, which started from VI, one per bundle, stout, straight, with blunt , double -pointed or simple distal end Plate $3 \mathrm{~d}$ ). All ventral chaetae of one form, 2-6 per bundle with longer upper tooth, those of II longer than the rest, in II-V with proximal to medium nodulus, in the following segments the nodulus medium- distal. (Plate 3eThis species is considered as a new record to Iraq, while in turkey it was recorded by ( 35,36 , and 37$)$. Previously this species was recorded in Japan by, (27); South Africa ( 33); and in Argentine (38).

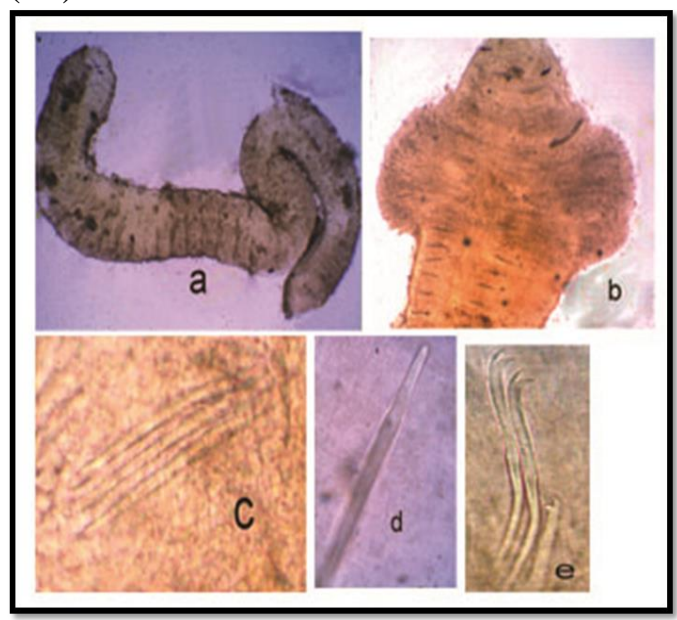

Plate 3: Ophidonais serpentina

a: whole asexual worm b: anterior end of sexual individual showing clitellar region; c: penial chaetal bundle ; d: dorsal chaeta; e:ventral chaetae 
4-Specaria josinae.( Vejdovsky, 1883)

Only six individuals were sorted during January and February, with average length of $6.2 \mathrm{~mm}$. Eye absent (plate 4a). This species is characterized by the presence of hair chaetae and needle chaetae in the dorsal bundles (plae 4b. Dorsal chaetae beginning in VI, with 2-3 needle and1- 2 hair ; needles resemble ventral chaetae, but slightly straighter, with equal teeth, and a distal nodulus, hair chaetae twice as long as needle., Ventral chaetae all of one type, 3-4 per bundle, curved in which the upper tooth is equal but slightly thinner than the lower one, and median nodulus. ( plate $4 \mathrm{c} \& d$ ). This species was recorded in Turkey by (39), and (11) referred to it in North East Europe .

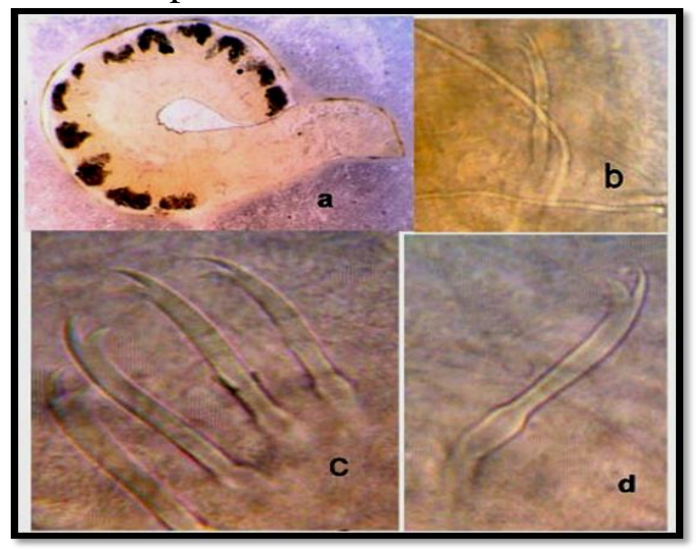

Plate 4: Specaria josinae

a, whole worm; b, dorsal bundle; $\mathrm{c}$,anterior ventral bundle; $\mathrm{d}$, posterior ventral chaeta

5-Dero (Dero) evelinae Marcus, 1943

Four individuals were sorted with average length of $8.6 \mathrm{~mm}$ and about 37 segments. Eye absent. Dorsal bundles start from VI with 1 hair and I bifid needle, needles with single intermediate tooth (plate5 b\&c). Ventral bundles of II-V, with 3-4 chaetae, longer than the rest, with dorsal tooth 1.5 time as long as the lower one, nodulus proximal (plate 5d). Ventral chaetae from VI on , 4-5 per bundle, , with thicker lower tooth , but as long as upper one. (plate 5e).
Brachial fossa with 8pairs of fingerlike gills, partly bilobed.( plate $5 \mathrm{f}$ ).

(10) referred to presence of this species in Brazil, and it recorded in Argentine by( 25).

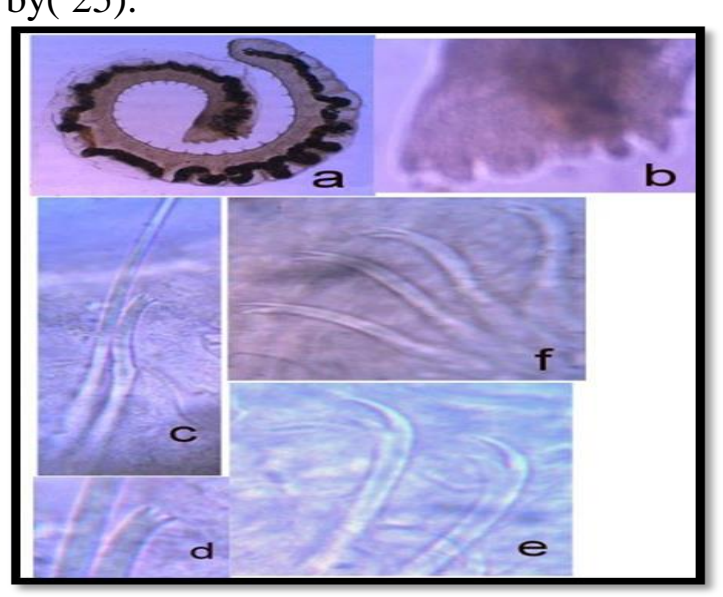

Plate 5: Dero (Dero) evelinae

a:, whole worm; b: brachial fossa; c: dorsal bundle d: tip of needle chaeta ; e, tip of the anterior ventral chatae; f: posterior ventral bundle

\section{6-Dero (Aulophorus) indicus}

Stephenson 1931

Prostomium trianglular (Plate 6b), eyes absent, brachial fossa, wide, cupshape with three pairs of gills and one pair short divergent palps( plate 6b). dorsal chaetae from $\mathrm{V}$, contains 1 bayonet- shaped hair chaetae, and 1needle, with equal teeth, some of them with one middle intermediate tooth, and some others have no intermediate tooth ( plate $5 \mathrm{~d}$ ). Ventral chaetae 3-4 per bundle, those of II-V with proximal nodulus and thinner upper tooth, but about twice as long as lower tooth (plate $6 f \& g$ ),. From VI, ventral chaetae with upper tooth thinner but as long as lower one , shorter posteriorly.(Plate 6h) . This species was recorded by (11) in Europe, and in Turkey by (40). 


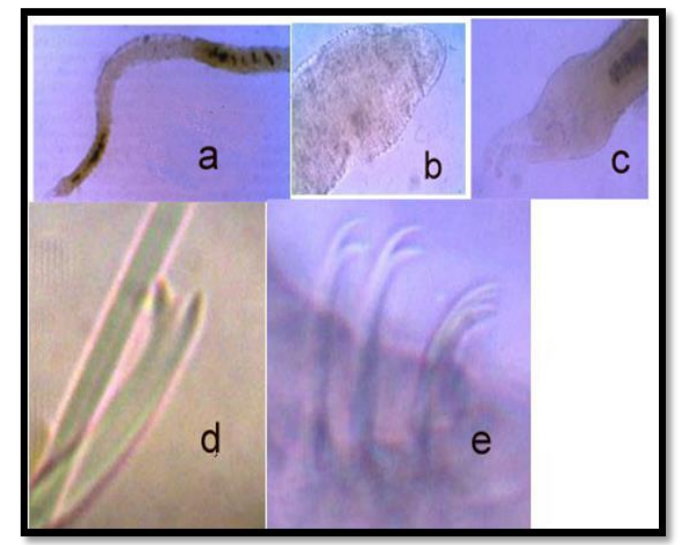

Plate 6: Dero (Aulophorus) indicus

a, posterior portion of worm shawing region of budding; $b$, anterior portion of the worm; c, brachial fossa; d, dorsal chaetal bundle; e, ventral chaetal bundle

\section{7-Nais pseudobtusa (Piguet 1942)}

Number of individuals collected was only five, with average length of $3.5 \mathrm{~mm}$. and 17 segments . Eyes conspicuous (Plate7a). Dorsal chaetae, with hair and needle, 1-2 each per bundle, Needle with long pointed tip, and nodulus $1 / 3$ from the tip (plate $7 b$ ). Ventral chaetae in the anterior segments (II-V), 3-4 per bundle, longer and straighter than the rest, with upper tooth about 1.5 time as long as lower on, and proximal nodulus ( plate $7 \mathrm{c}$ ). Segments from VI on, with ventral chaetae 2-4 per bundle, thicker than the former, with distal nodules, and slightly longer but thinner upper tooth (plate7d). This species is cosmopolitan recorded in Asia, Africa , and South America(10). It was recorded in North America ( 41), North East Europe ( 11) ; South America (33)., Australia (42) and in Estonia (43). In Turkey the species was recorded by (31 \& 37).

8-Nais stolci (Hrabe, 1981)

Ten individuals were sorted belong to this species with average length of $2.3 \mathrm{~mm}$ and average number of segments was 28 . In this species eyes relatively small, dorsal bundles contain one hair and one needle chaeta per bundle ( plate 8a). Needle chaeta have paralle long parallel teeth( Plate $8 b$ ). ventral bundles with 3-5 chaetae per bundle. Ventral bundles of II-V have long thin chaetae with upper tooth twice as long as lower tooth (plate 8c). From VI - XII 2-3 enlarge chaetae per bundle with upper tooth 4 times longer than lower one (plate $8 \mathrm{~d} \& \mathrm{e}$ ), the number of chaetae in each bundle increase to 4-5 per bundle and the upper tooth decrease gradually to reach equal length in the posterior bundles.(Plate 8f). This species was mentioned by (11) in Europe, and it was recorded by (40) in Turkey.

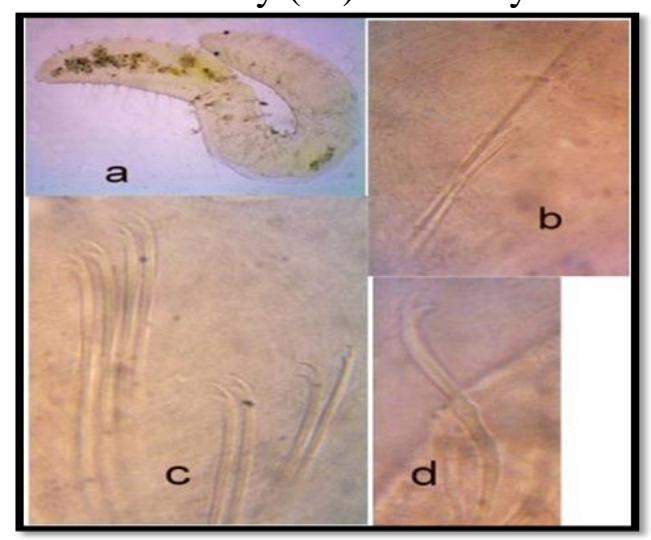

Plate 7: Nais pseudobtusa

a: whole mount; b: dorsal bundle; c: ventral chaeta of II; d: posterior ventral chaeta

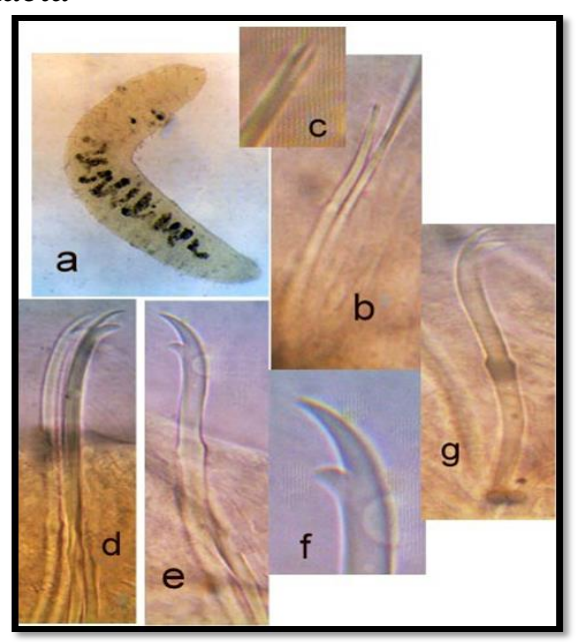

Plate 8: Nais stolci

a: whole mount; b: dorsal bundle; c: tip of the needle chaeta; $d$ : ventral bundle of II; e: ventral bundle of VI; $\quad f$;, tip of $t$ the ventral chaeta of IIX; $g$ :posterior ventral chaetae 


\section{References:}

1- Martins, R.T. and Alves, R.da G. (2008). Occurrence of Naididae (Annelida: Oligochaeta) from three Gastropod species in irrigation fields in Southeastern Brazil. Biota Neotropica, 8: 255-257.

2- Erséus, Ch. and Gustarsson, L. (2002). A proposal to regard the former family Naididae as a subfamily within Tubificidae (Annelida, Clitellata). Hydrobiologia, 485:253256.

3-Alves, R. da G. and Gorni, G.R. (2007). Naididae species (Oligochaeta) associated aquatic macrophytes in two reservoirs (São Paulo, Brazil). Acta Limnol. Bras., 19(4): 407-413.

4-Gorni, G.R. and Alves, R.da G.( 2007). Naididae (Annelida, Oligochaeta) associated with briophytes in Brotas, State of Sao Paula, Brazil. Revista Brasileira de Zoologia 24 (2): 518-519.

5-Armendáriz, L.C. (2000). Population dynamics of Stylaria lacustris (Linnaeus, 1767) (Oligochaeta, Naididae) in Los Talas, Argentina. Hydrobiologia, 438:217-226.

6-Corbi, J.J., Trivinho-Strixino, S. and Alves, R.G. (2005). Records of oligochaetes in freshwater sponges, on bryozoarians and on colonial hydrozoans from Brazil. Braz. J. Biol., 65(1): 187-188

7-Conn, D.B., Ricciardi, A., Babapulle, M.N., Klein, K.A. and Rosen, D.A. (1996). Chaetogaster limnaei (Annelida: Oligochaeta) as a parasite of the zebra mussel Dreissena polymorpha, and the quagga mussel Dreissena bugensis (Mollusca: Bivalvia). Parasitology Research, 82: $1-7$.

8- Gorni, G.R., and Alves, R. da G. (2006). Naididae (Annelida, Oligochaeta) associated with Pomacea bridgesii (Reeve) (Gastropoda Ampullaridae). Revista Brasileira de Zoologia, 23(4): 1059-1061.
9-Sharapova, T.A. (2010).Abiotic and biotic factors affecting zooperiphyton development in a water flow of a cooling water pool. Contemporary Problems of Ecology, 3(4): 495-497.

10-Brinkhurst, R.O. and Jamieson, B.G.M. (1971). Aquatic Oligochaeta of the world. Univ. of Toronto Press. Toronto, Canada. 860 pp.

11-Timm, T. (2009). A guide to the freshwater Oligochaeta and Polychaeta of Northern and Central Europe. Lauterborina, 66:1-235.

12-Erséus, Ch., Källersjö, M., Ekman, M. and Hovmöller, R .(2002). $18 \mathrm{~S}$ rDNA phylogeny of the Tubificidae (Clitellata) and its constituent taxa: dismissal of the Naididae. Molecular Phylogenetics and Evolution, 22: 414422.

13-Erséus, Ch., Wetzel, M.J. and Gustavsson, L. (2008). ICZN rules-a farewell to Tubificidae (Annelida, Clitellata). Zootaxa, 1744: 66-68.

14-Ali, L.A.( 2007). A study of macroinvertebrates community in the middle sector of Greater Zab River / Iraq. Ph.D. thesis, College of Science for Women, Baghdad Univ., 123pp.

15-Sabtie, H.A. (2009). An ecological study of the benthic macroinvertebrates community in the Southern Marshes of Iraq. Ph.D.thesis, Colloge of Science for Women, Baghdad Univ., 167pp.

16-Al-Abbad, M.Y. (2009). Identification and Biology of the species Chaetogaster limnaei von Baer 1827 (Oligochaeta: Naididae) Isolated from some Basrah marshes snails in the south of Iraq. Ph.D. thesis, Basrah Univ., $145 \mathrm{pp}$.

17-Al-Abbad, M.Y. (2010). New records of Pristina proboscidea and P.aquiseta (Oligochaeta : Naididae) from Iraq. Marsh Bulletin, 5(2): 132142.

18-Al-Abbad, M.Y. and AL-Mayah, S.H. (2010). New records of two species of oligochaetes (Nadidae): Pristina longiseta and P.macochaeta 
from Iraq, with notes on their morphology and reproduction. Mesopot .J. Mar. Sci., 25(2): 57-66.

19-Jaweir, H.J. ( 2011). Anew record of three tubificid species ( Annelida: Oligochaeta) from Al- Hawiezah marsh, Iraq.

20-Jaweir, H.J. Sabtie. H.A. and Almukhtar, E. A. (2012). Aquatic Oligochaetes of Iraq's Southern Marshes. Journal of Baghdad for Science, 9(3):472-480

21-Rhadi, M.M. ( 2012 ). Sorting and Identification of Naididae and aeolosomatidae (Annelida) species from Different aquatic sites within Baghdad city. MSc thesis college of Science for Women, University of Baghdad/ Iraq. 118pp.

22-Naidu, K. V., (1966). Check-list of fresh- water Oligochaeta of the Indian Sub- continent and Tibet. Hydrobiologia, 27: 208-226.

23- Maciorowski,A. F., Benfield, E.F.and Hendricks, A.C.(1977). Species composition, distrbution and abundance of oligochaetes in the Kanawha River, West Virginia. Hydrobiologia,54(1):81-91.

24- Grimm, R. (1987). Contribution towards the taxonomy of the African Naididae (Oligochaeta). IV. Zoogeographical and taxonomical considerations on African Naididae. Hydrobiologia, 155: 27 -37.

25-de Pascar, C.G. (1987).Aquatic Oligochaeta in some tributaries of the Rio de La Plate, Buenos Aires Argentina. Hydrobiologia, 144:125130.

26- Armendariz,L.C. and Cesar, I.I. (2001). The distribution and ecology of Littoral Oligochaeta and Aphanoneura (Annelida) of the Natural and Historical Reserve of Isla Martin Garcia, Rio de Ia Plata River, Argentina. Hydrobiologia, 463: 207216.

27-Ohtaka,A. \& Nishino, M. ( 1999). Studies on the aquatic oligochaeta fauna in lake Biwa, central Japan II. Records and taxonomic remarks of nine species. Hydrobiologia, 40: 33- 4 28-Lin, K.J. and Pin YO, S. (2008). The effect of organic pollution on the abundance and distribution of aquatic Oligochaetes in an Urban water basin, Taiwan. Hydrobiologia, 586(1): 213223.

29- Paoletti, A. de C. \& Samburgar, B. (1996). Aquatic Oligochaeta in Italy, with special reference to the Naididae. Hydrobiologia, 334: 37-49.

30- Balik, S.;Ustaoglu,M.R.; and Yildiz,S.(2004). Oligochaeta and Aphanoneura ( Annelida) fauna of the Gediz Delta ( Menemen-Izmir). Turk. J. Zool., 28: 138-197.

31-Yildiz, S. ;Rusen, M. and Balik, S.(2007). The Oligochaeta (Annelida) Fauna of Yuvarlak stream (Koycegiz Turkey).Turkish Journal of Fisheries and Sciences 7: 01- 06.

32-Wang, H. and Liang, Y. (2001). A preliminary Study of Oligochaetes in Poyang Lake, the Largest freshwater Lake of China, and its vicinity, with description of a new species of Limnodrilus. Hydrobiologia 463: 2938.

33-Christoffersen, M. L. (2007). Acatalogus of aguatic microdrile oligochaetes (Annelida: Clitellata) from South America. ACTA HYDROBIOLOGICA SINICA, 31: 59- 86.

34-Pinder, A.(2010). Tools for identifying selected Australian aquatic Oligochaetes (Clitellata: Annelida). Museum Victoria Science Reports ,13: 1- 26.

35-Arslan, N. and Sahin, Y. (2003). Nine new Naididae(Oligochaeta) species for Sakarya river, Turkey. Turk. J. Zool., 27: 27 -38.

36-Arslan, N. and Sahin, Y. (2006). Apreliminarey Study on the Identification of the Littoral Oligochaete (Annelida, Dipter and Chironomidae Fauna Lake Kovada, a 
National Park in Turkey. Truk J Zool, 30: 67- 72.

37-Arslan, N. and Ilhan, S. (2010).

Distribution and abundance of Oligochaeta (Annelida) species and environmental variables of Porsuk Stream (Sakarya River, Turkey). Review of Hydrobiology, 3(1): 51 -63. 38-Nijboer, R.C., Wetzel, M.J. and Verdonschot, P.F. (2004). Diversity and distribution of Tubificidae, Naididae, and Lumbriculidae (Annelidae: Oligochaeta) in the Netherlands : an evaluation of twenty years of monitoring data. Hydrobiologia, 520: 127 - 141.

39-Sarkka, J. (1994). Lacustrine, profundal meiobenthic Oligochaetes as indicators of trophy and organic loading. Hydrobiologia, 278: 231- 241. 40-Yildiz, S. and Ahiska, S. (2010). Nais stolci Hrabe, 1981. A new Oligochaeta (Annelida: Clitellata:
Naididae) species for Turkey. Turk. J. Zool, 34: 547- 549.

41- Cardenas, C.I.B. and Velez,I. (2007). Aquatic Oligochaeta (Annelida: Clitellata) of the department of Antaioquia, Colombia, South America. Acta Hydrobiologica Sinica, 31: 52-58.

42-Kathman, R. D. and R. O. Brinkhurst, (1998). Guide to the Freshwater Oligochaetes of North America. Aquatic Resources Center, Tennessee: 264 pp.

43-Naidu, K.V. and Naidu, K.A. (1980). Nais pseudobtusa Piguet, 1906 (Oligochaeta: Naididae) new to Australia. Hydrobiologia, 68:91-92.

44-Timm, T. ; Kumari, M. ; Kubar, K. ; Sohar, K. and Traunspurger, W. (2007). Meiobenthos of some Estonian Coastal lakes. Estonian Acad. Sci..Biol..Ecol., 56(3) 179- 195.

\section{تسجيل جديد لأنواع ديدان النايدد في نهز الفرات عند مدينة المسيب جنوب غرب بغداد إلهام عبيا صالح الجنابي***

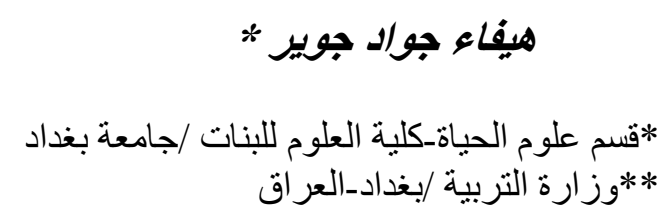

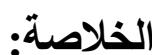

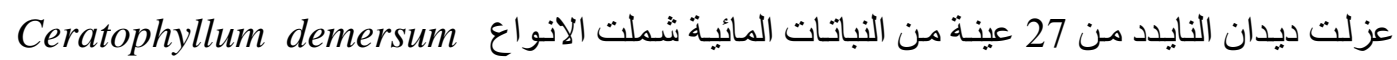

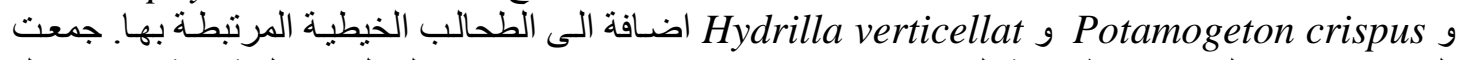

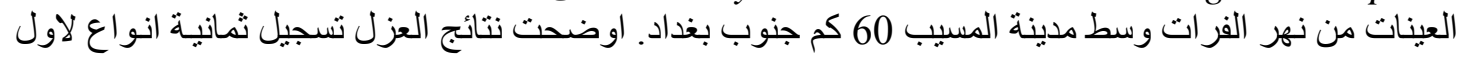
مرة في العراق وشملت الانواع Stephensoniana trivandrana و و و و Dero (Aulophorus) indicus و, Dero (Dero) evelinae و Specaria josinae و serpentine

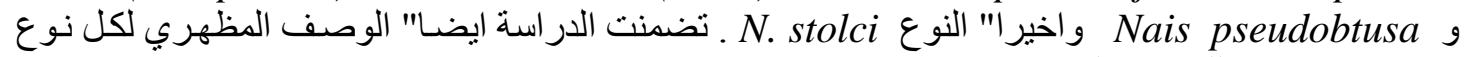
موضحا" بصور للصفات التشخيصية . 